Issue $3 / 2017$

\title{
KNOWLEDGE MANAGEMENT STRATEGY TO IMPROVE BUSINESS SECTOR
}

\author{
Haradhan Kumar MOHAJAN ${ }^{1}$ \\ ${ }^{1}$ Premier University, Chittagong, Bangladesh, \\ Email: haradhan1971@gmail.com
}

\begin{abstract}
Every organization needs the proper knowledge management (KM) strategy for its development. In the last decades, the business environment has changed and recently it became more dynamic and more complex. At present, $K M$ is valuable not only for individuals, and organizations, but also for global humanity. So, the directors of the organizations must emphasize on the existing knowledge and try to develop them to achieve the competitive advantage.

The purpose of the study is to explore the recent KM practice in the organizations and to show the ways to develop the new KM strategy in future. An attempt has been taken here to apply KM strategy in business performance, business intelligence, and e-business.
\end{abstract}

Keywords: knowledge; knowledge management; business intelligence; business performance; e-business.

JEL Classification: $\mathrm{M}_{1}, \mathrm{M}_{15}$

\section{Introduction}

In the $21^{\text {st }}$ century, the organizations are facing considerable challenges to survive in a dynamic state and the continuous developments and changes in the internal and external work environment. Recently, knowledge becomes an essential asset in any organization. Hence, interest in knowledge management (KM) has increased rapidly for the improvement of business. KM represents one of the greatest challenges for the running of an organization.

The present society is gradually turning into a knowledge-based society [Shehzad \& Khan, 2013]. Since the 1990s, knowledge has become one of the essential and valuable assets of business organizations. Organizations should manage knowledge in effective and efficient ways [Faucher, 2010]. The rapid advancement 


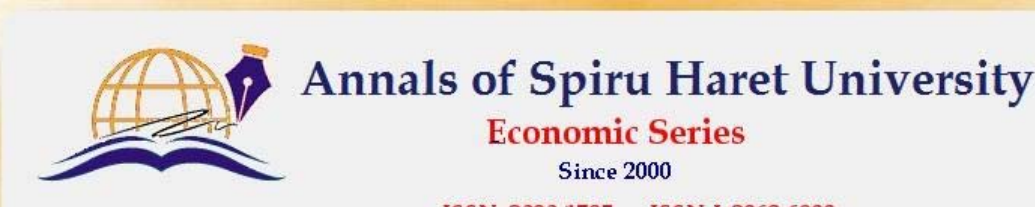

ISSN: 2393-1795 ISSN-L:2068-6900

Issue 3/2017

in Information and Communication Technology (ICT) has made a revolutionary change in business [Khan, 2012].

The word knowledge is one of the most confusing aspects in the KM theory due to the confusion among knowledge, information, and data. Knowledge is built up from data, information and prior knowledge. Data refer to raw facts without any processing, organizing or analysis, and hence they have little meaning and few benefits to managers and decision-makers. Data are un-interpreted materials on which a decision is to be based and depend on facts which may include anything known to be true or exist [Klicon, 1999]. Information refers to data that are accumulated to allow comparison, grouping, and categorizing which have been processed to be useful [Cong $\&$ Pandya, 2003]. Knowledge is derived from information but it is more meaningful than information [Servin \& de Brun, 2005]. Knowledge is the most useful form of contents for problem-solving and decision-making since it has more meaning than data and information [Davenport, 1997].

In organizations, knowledge is divided into two types: tacit knowledge and explicit knowledge [Nonaka, 1991]. Tacit knowledge consists of the hands-on skills, best practices, special know-how, heuristic, intuitions, and so on [Polanyi, 1973]. Data and information encoded, stored and disseminated are known as content component of the explicit knowledge [Mahmood et al., 2011]. It is easily coded, transferred and shared within an organization [Nonaka, 1994].

At present, the business organizations are in competition among them to create more markets, more customers, and more sales, by reducing cost, producing efficient and innovative products. Obviously, these goals will be achieved through the human resources management (HRM) in business organizations.

A successful business has a clear purpose, set goals to achieve the purpose and established procedures design to meet those goals consistently. For a successful business, every business organization needs to ensure that it is operating the business as efficiently and effectively as possible [Barned, 2011].

\section{Literature Review}

According to Ikujiro Nonaka and Hirotaka Takeuchi, the first generation KM concepts treated knowledge as a thing, and second generation KM develops knowledge as a process which is partially explicit and tacit [Nonaka \& Takeuchi, 1995]. The third generation KM deals with the function of knowledge ecology, chaos and the sensing of opportunities [Scharmer, 2001].

Gashaw Kebede analyzes the KM in information science (IS). He shows that the members of the IS profession can take a more proactive and visible role in 20 


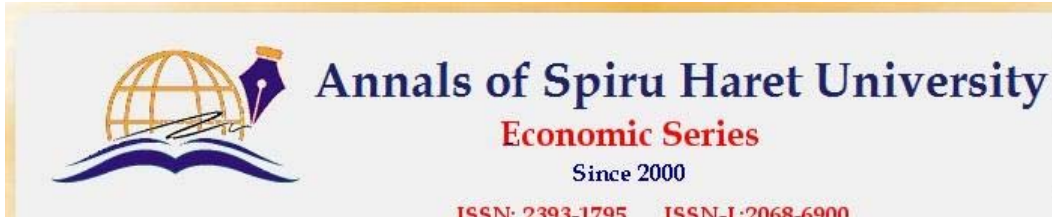

ISSN: 2393-1795 ISSN-I-2068-6900

Issue $3 / 2017$

advancing $\mathrm{KM}$ by showing that $\mathrm{KM}$ is a natural and long-awaited development in IS [Kebede, 2010]. Oluwole Adekanmbi and Paul Green (2015) have emphasized that the design of an efficient KM service needs to incorporate four interacting dimensions as: i) knowledge, ii) technology, iii) workflow, and iv) stakeholder stipulations for service needs and usage preferences. Swan et al. (1999) have indicated that $\mathrm{KM}$ is rooted in the following fields: IT systems and principles, including artificial intelligence business process reengineering, information systems, expert systems, decision support systems, data mining, and data warehousing.

H. M. Campbell has proposed ten principles that managers can use to create $\mathrm{KM}$ initiatives which focus on the systems which an organization should adopt to transform KM into business intelligence (BI) [Campbell, 2006]. Jayanthi Ranjan has explored the concepts of BI, its components, emergence of BI, factors influencing BI, technology requirements, designing and implementing BI, benefits of BI, and various BI techniques [Ranjan, 2009].

Hengshan Wang and Liqun Ji have discussed the effective KM environment in business organizations for sustainable growth and development. They have also analyzed the environmental problems of most of the business organizations; especially those that are knowledge-based [Wang \& Ji, 2005].

J. Valacich and C. Schneider (2010) express that e-business in the digital network enhances four components such as: i) the inputs of the business, whether they take on characteristics of raw materials or other information, ii) resources, both human and capital, iii) the practices of e-commerce, and iv) management and analysis of processes taking as a tool to support customer feedback.

\section{Objectives of the Study}

The purpose of this study is to discuss the KM strategy for the improvement of business organizations. The objective of the study is to discuss the KM in the following areas:

- application of KM processes in business;

- to improve the business performance;

- to discuss e-business; and

- to discuss business intelligence (BI).

\section{Methodology}

Methodology of the study is the systematic procedure that maps out the processes, approaches, techniques, research procedures and instruments [Kothari, 


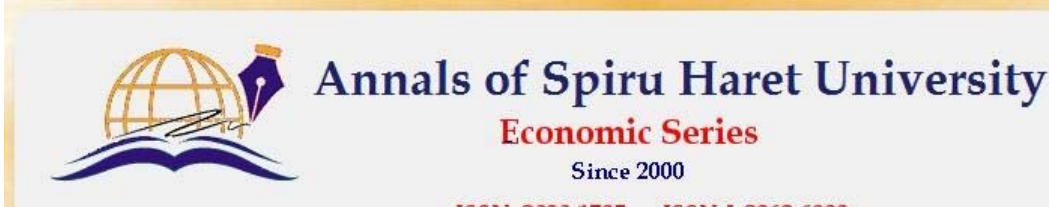

ISSN: 2393-1795 ISSN-L:2068-6900

Issue $3 / 2017$

2004]. To prepare this paper, we have used the secondary data. In this study, we have used websites, books, previous published articles, theses, conference papers, case studies and various research reports. At the present globalized world, we cannot develop a sustainable business environment without proper KM in business.

\section{Knowledge and Knowledge Management}

Knowledge is considered as an asset that helps both individual and organizational performance to achieve expected goals. Knowledge and knowledge management (KM) represents one of the most challenges for the propelling of an organization. Hence, it is necessary for business organizations to apply KM strategy properly. At present, KM becomes an essential issue to the business consultants and researchers.

In the historical view, there are three generations of KM: the first generation of KM was from 1990 to 1995 , when many attempts were taken to define KM and future benefits of research on this field [Nonaka, 1994]. It takes into account knowledge sharing that focuses on IT-driven KM [Koenig, 2002].

The second generation of KM started in 1996 and ended at the early $21^{\text {st }}$ century. It explored corporate philosophies, building systems, development of corporate models, and development of advanced technologies. It indicates that we can improve the quality of knowledge by actively managing KM [Metaxiotis et al., 2005; Chau \& Goh, 2009]. It has focused on tacit-explicit knowledge conversion, and generated by the socialization, externalization, combination and internalization (SECI) model of Nonaka [Nonaka \& Takeuchi, 1995]. Organizations continuously seek ways to survive, develop and flourish themselves in any situation in a competitive marketplace [Albert, 1997]. But many organizations are unable to prepare them as knowledge-based organizations, because they suffer from learning disabilities. The organizations which can make their environment as knowledge-based can progress to the development [Senge, 1990].

The third generation of KM, based on complexity theory, has just started recently. It is considered as a deep knowledge era. It demands robust knowledge discovery and knowledge capture processes. It highlights the relevance of chaos, complexity and paradox, and frames them as critical KM resources [Grant \& Grant, 2008]. It emphasizes value creation and represents key challenges faced by modern organizations. The value creation is grounded in the appropriate combination of human networks, social capital, intellectual capital, technology assets, and change processes [Vorakulpipat \& Rezgui, 2006]. 


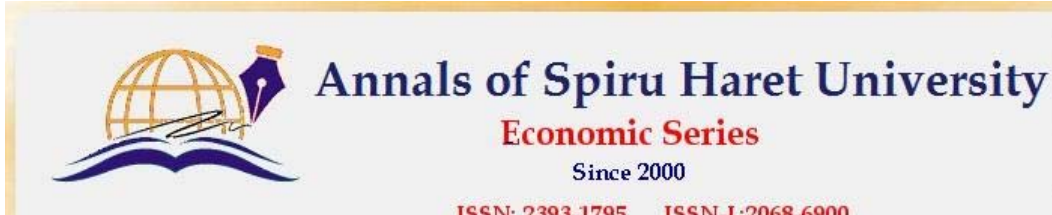

ISSN: 2393-1795 ISSN-I-2068-6900

Issue $3 / 2017$

At present many organizations are suffering from the sustainable development due to the lack of proper use of knowledge. More conscious and proper KM can bring significant contributions and benefits to the business organizations.

KM can be considered as a systematic process of identifying, creating, capturing, acquiring, storing, sharing, organizing, transferring, sustaining, retrieving, renewing, evaluating and utilizing both explicit and implicit forms of knowledge at individual, group, organizational and community level through harnessing of people, process and technology to enhance organizational performance and create value [Alavi \& Leidner, 2001; Madhoushi et al., 2010; Rašula et al., 2012]. KM enhances the organization's business performance by providing collaborative tools to learn, create, and share the knowledge within the business organization [Gadu \& ElKhameesy, 2014].

Information technology (IT) perspective of KM focuses on the use of various technologies to acquire or store knowledge resources [Borghoff \& Pareschi, 1998]. Socialization of KM focuses on understanding organizational nature [BecerraFernandez \& Sabherwal, 2001]. Information system of KM focuses on both IT and organizational capability perspectives and emphasizes in the use of knowledge management systems (KMS) [Schultze \& Leidner, 2002].

\section{KM and Business Performance}

As the business environments are changing very rapidly, the Chief Executive Officers (CEOs) of many organizations have realized that they need to develop an effective KM strategy. They are employing the best knowledge experts/talents to support their organizations for sustainable development. But, it is a matter of regret that many organizations are still unable to explain what knowledge is, and they are quite unable to develop and leverage knowledge to improve organizational performance.

There is no direct relation between KM and business performance, but they have a complex relationship among various related theories [Carlucci et al., 2004]. A recent survey on KM within companies has shown different impacts of KM initiatives on business performance [Heisig, 2003].

According to Campbell's (1999) theory, performance is a behavior or action relevant to the achievement of an organization's goals that can be measured. The overall goal of business performance is to create a culture as high performance in which individuals and teams to take responsibility for the continuous improvement of business processes and their skills and contribute in achieving the targets set by managers [Armstrong, 2006]. It enables organizations to achieve significant and 


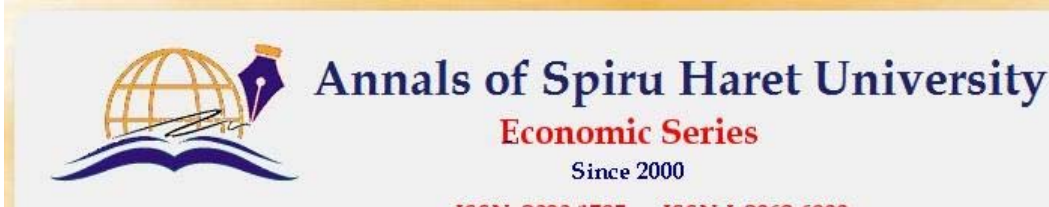

ISSN: 2393-1795 ISSN-L:2068-6900

Issue 3/2017

measurable performance improvements by focusing on improvement levers that enhance agility, scalability, speed to market, quality, reliability and customer value.

\section{Business Intelligence}

Business intelligence (BI) can be defined as an organization's ability to gather all its capabilities and skills, and transform them into knowledge [Schick et al., 2011]. Stackowiak et al. (2007) define BI as the process of taking large amounts of data, analyzing those data, and presenting a high-level set of reports that condense the spirit of those data into the basis of business activities, which enable management to make fundamental daily business decisions. BI refers to various software solutions (technologies and methodologies) to acquire the right information which is necessary for the business decision-making with the major purpose of enhancing the overall business performance on a marketplace [Wang \& Wang, 2008]. It is a new working culture with information and a specific methodology to work with information and knowledge, open communication, and knowledge sharing [Negash \& Gray, 2008]. It is considered a broad category that covers technologies, applications and processes, which is responsible for the collection, storage, data access and share, and analysis to take accurate and effective decisions [Wixom \& Watson, 2010]. It plays an important role for gathering both internal and external sources of data for the development of business [Shehzad \& Khan, 2013].

\section{Structure of $B I$}

$\mathrm{BI}$ is formed by a set of various software technologies as [Olszak \& Batko, 2012]: data warehouse (DW), data marts, data mining, online analytical processing (OLAP), extraction transform load (ETL) and other reporting applications. These are needed to acquire the right information for the business decision-making to enhance the overall business performance [Rao \& Kumar, 2011].

DW: It is an integrated collection of the summarized and historic data, which is collected from internal and external data sources [Radonic, 2007]. It is the significant component of BI, and subject oriented and integrated. It supports the spread of data by handling the numerous enterprise records for integration, cleansing, aggregation and query tasks. It contains live and prepared data, not snapshots, and retains minimal history for tactical decision-making of business area. It stores data as tables or spreadsheets, or unstructured information, such as plaintext files or pictures and other multimedia information [Ranjan, 2009].

Data marts: These are small sized DWs, usually created by individual departments [Khan, 2012]. These are a collection of subject areas organized for 24 


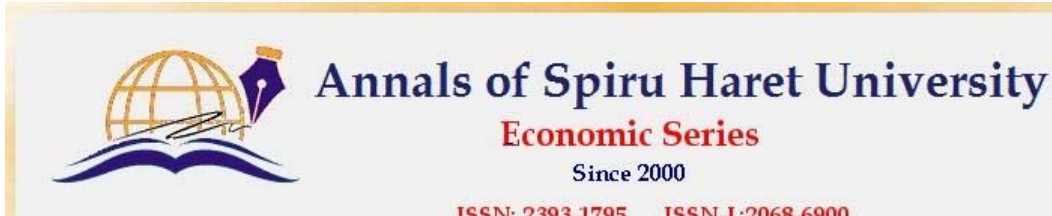

ISSN: 2393-1795 ISSN-I-2068-6900

Issue $3 / 2017$

decision support based on the needs of a given department. These help business experts for the analysis of past trends and experiences. A data mart can support a particular business function, business process or business unit [Inmon, 1999].

Data mining: It is a method of finding patterns, correlation, generalizations, regularities and rules in data resources and trends by modifying through the large amount of data, which is stored in the warehouse. For example, recognition technologies, statistical and mathematical techniques are considered as data mining [Muhammad \& Ibrahim, 2014].

OLAP: It is the technology that enables the user to interact, analyze, report and present the data in the DW. It represents a form of a multidimensional and summarized business data analysis, and is used for reporting, analysis, modeling and planning for optimizing the business [Panian \& Klepac, 2003]. It refers to the way in which business users can slice and dice their way by using complicated tools that allow for the improvement of business [Ranjan, 2009]. It allows to access and model business problems, and share information that is stored in DW. The purpose of it is to get answers on questions related to the increase or decrease of sales, price elasticity, sales oscillations and all other determinants of the business operations [Sabherwal \& Fernandez, 2011]. It covers many business areas upon which decisions are made. It starts with data, continues with information, and ends with BI. A special feature of OLAP is the speed of acquiring very complex data that cover a number of variables [Panian \& Klepac, 2003].

ETL: It is a set of actions by which data are extracted from numerous databases, applications and systems, transformed as capture, and are loaded into target database. It is responsible for data transfer from operational or transaction systems to DW (Gadu \& El-Khameesy, 2014).

Ages of BI

$\mathrm{BI}$ is divided into three ages depending on the development of the society [Gratton, 2012]: i) BI 1.0, ii) BI 2.0, and iii) BI 3.0.

The $1^{\text {st }}$ age of BI (between 1970s and 1980s) is called BI 1.0, which is closely related to the management information systems (MIS), executive information systems (EIS), and decision support systems (DSS). It is able to process the simple tasks for operational and tactical management.

The $2^{\text {nd }}$ age of BI (1990-2005) is called BI 2.0, which indicates concepts and methodologies for the improvement of business decisions using facts and information from supporting systems. It is illustrated by end-user friendlier client-based BI tools and centralized [Power, 2007]. It is used in strategic planning, predictive 


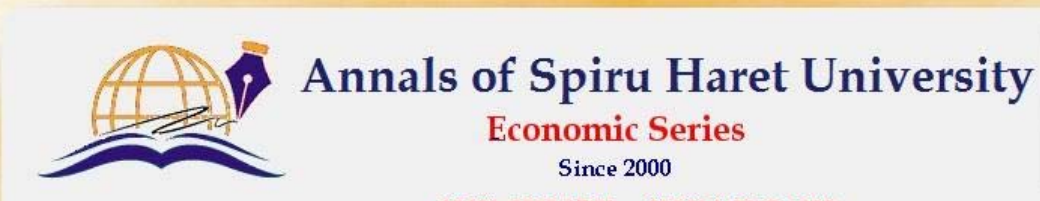

ISSN: 2393-1795 ISSN-L:2068-6900

Issue 3/2017

modeling, forecasting, monitoring operations, and studying the profitability of products [Negash \& Gray, 2008].

Now we are living in the $3^{\text {rd }}$ age of BI which is called 3.0. It presents a new era in the evolution of BI. For example, web and mobile technologies are using in BI network. N. Scott has indicated that there are five core attributes that support BI 3.0 philosophy as [Scott, n. d.]; i) proactive, ii) real time, iii) integrated with business processes, iv) operational, and v) extended. These help to reach beyond the boundaries of the organizations to improve information delivery and decision support functionality for all.

\section{Importance of BI}

As business organizations face vast quantities of information, so they need right information for the successful business. BI helps to identify the causes and reasons of certain problem to make predictions, calculations and analyses. For this, knowledge is needed for the proper decisions receiving [Zekić-Sušac, 2008]. Due to $\mathrm{BI}$, the organizations are making more effective decisions, improving business processes, and business performance [Olszak \& Ziemba, 2006]. At present, trading companies, insurance companies, banks, the financial sector, the health sector, telecommunications, and manufacturing companies are using BI efficiently.

$\mathrm{BI}$ improves the overall performance of the company and some of them are as follows [Olszak \& Ziemba, 2006; Ranjan, 2009]:

- Firms can identify their most profitable customers.

- Investigates customer loyalty and customer switching to competition.

- Detects customer segmentation and profiling.

- Analyzes click-stream data to improve e-business strategies.

- Finds out money-laundering criminal activities.

- Examines that supports cross selling and up selling.

- Sets more profitable rates for insurance premiums.

- Reduces equipment downtime by applying predictive maintenance.

- Employees can easily convert their business knowledge to solve many business issues.

- Quickly detects warranty-reported problems to minimize the impact of product design deficiencies.

- Analyzes potential growth customer profitability and reduces risk exposure through more accurate financial credit scoring of their customers. 


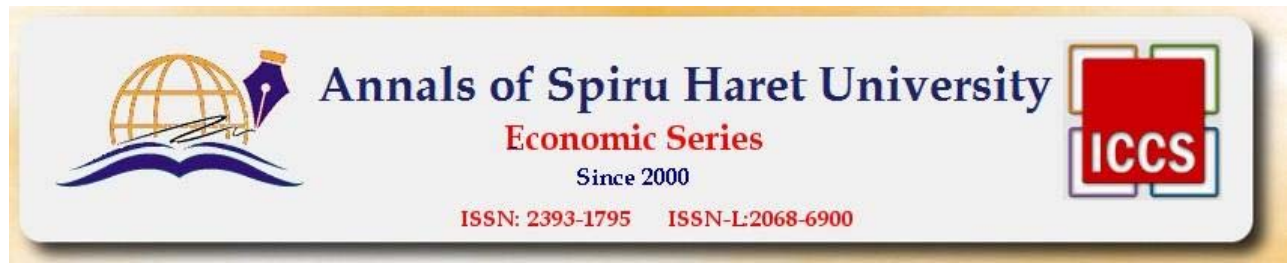

Issue $3 / 2017$

- Decides what combinations of products and service lines customers are likely to purchase and when.

- Detects and deters fraudulent behavior, such as from usage spikes when credit or phone cards are stolen.

- Analyzes the assessment of the internet services performance.

- Forecasts the strategic business processes development.

By using BI, organizations can realize [Ranjan, 2009]; i) the position of the firm as in comparison to its competitors, ii) change in customer behavior and spending patterns, iii) the social, regulatory, and political environment, iv) the capabilities of the firm, and v) market conditions, future trends, demographic, and economic information of the business. Business organizations need to manage explicitly their intellectual resources to gain and sustain a competitive advantage [Wiig, 1997].

\section{$\mathrm{KM}$ in e-business}

By the emergence of World Wide Web (www) the application of e-business emerged in the beginning of 1990s. Companies explore it to compile, disseminate and exchange information with current and potential customers. The influence of ebusiness is wide spread and brings changes in customer satisfaction, business processes optimization, higher turnover, etc. [Ngai \& Wat, 2002].

Strauss et al. (2003) define e-business as the role model based on digital features and market spaces that allows companies to attract and retain customers and to suit business partners to their characteristics.

The e-business is a new revolutionary procedure in modern business where is fully utilized the strategy of internet technology. This strategy brings competitive advantage among the competitors in the market through the configuration of its available resources to meet the needs of the market and customers. It is based on the research of value creation, reward for customers to build a strong trust between the company and its customers [Sheung, 2014]. The e-business can create additional customer value through knowledge creation with customers [Kodama, 2005]. Recent development of Information and Communication Technology (ICT) has grown interest for transforming traditional business to new developed technological innovation. It creates new opportunities for companies to go from the traditional market channels to a virtual market [Pateli \& Giaglis, 2003].

Now, many organizations globally have adopted e-business to leverage critical business processes, to explore the internet as a medium for transaction 


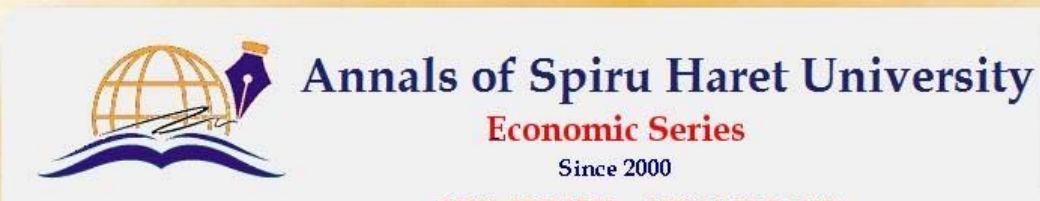

ISSN: 2393-1795 ISSN-L:2068-6900

Issue 3/2017

management, and allow access to a wide range of information, services and even remote access payment [Anderson et al., 2005].

\section{Conclusion}

In this paper we have discussed the development of the concepts of knowledge and $\mathrm{KM}$ in business organizations. We have tried briefly to describe business performance. We have also discussed aspects of business intelligence and e-business. We hope this study will provide partial benefits to KM planners, knowledge managers, and also to all employees of the organizations.

\section{References}

1. Adekanmbi, O. \& Green, P., "Assessment of User Authentication Risks in a Healthcare Knowledge Management System." International Business \& Economics Research Journal 14(1), (2015): 95-105.

2. Alavi, M. \& Leidner, D. E., "Knowledge Management and Knowledge Management Systems: Conceptual Foundations and Research Issues." MIS Quarterly 25(1), (2001): 107-136.

3. Albert, S., Managing Knowledge: Experts, Agencies, and Organizations (Cambridge University Press, 1997).

4. Anderson, B. B., Hansen, J. V., Lowry, P. B. \& Summers, S. L., "Model Checking for Design and Assurance of e-Business Processes." Decision Support Systems 39(3), (2005): 333-344.

5. Armstrong, M., Performance Management: Key Strategies and Practical Guidelines ( $3^{\text {rd }}$ Edition) (Kogan Page Limited, 2006).

6. Barned, J., Improving Business Performance (Australia: CPA Australia Ltd., 2011).

7. Becerra-Fernandez, I. \& Sabherwal, R., "Organizational Knowledge Management: A Contingency Perspective." Journal of Management Information Systems 18(1), (2001): 23-55.

8. Borghoff, U. M. \& Pareschi, R., Information Technology for Knowledge Management (New York: Springer, 1998).

9. Campbell, H. M., The Role of Organizational Knowledge Management Strategies in the Quest for Business Intelligence (The Institute of Electrical and Electronics Engineers (EEE), (2006).

10. Campbell, J. P., "The Definition and Measurement of Performance in the New Age." In D. R. Ilgen \& E. D. Pulakos (Eds.), The Changing Nature of Performance. Implications for Staffing, Motivation, and Development (San Francisco: Jossey-Bass, 1999), pp. 399-429. 
11. Carlucci, D., Marr, B. \& Schiuma, G., "The Knowledge Value Chain-How Intellectual Capital Impacts Business Performance." International Journal of Technology Management 27(6-7), (2004): 575-590.

12. Chua, A. Y. K. \& Goh, D. H., "Why the Whole is Less Than the Sum of its Parts: Examining Knowledge Management in Acquisitions." International Journal of Information Management 29(1), (2009): 78-86.

13. Cong, X. \& Pandya, K. V., "Issues of Knowledge Management in the Public Sector." Electronic Journal of Knowledge Management 1(2), (2003): 25-33.

14. Davenport, T. H. \& Prusak, L., Working Knowledge: How Organizations Manage What They Know (Harvard Business School Press: Boston, MA, USA, 1997).

15. Faucher, J-B. P. L., Reconceptualizing Knowledge Management: Knowledge, Social Energy, and Emergent Leadership in Social Complex Adaptive Systems. PhD Thesis (University of Otago: Dunedin, New Zealand, 2010).

16. Gadu, M. \& El-Khameesy, N., "A Knowledge Management Framework Using Business Intelligence Solutions." International Journal of Computer Science Issues 11(5), (2014): 102-107.

17. Grant, K. A. \& Grant, C. T., "Developing a Model of Next Generation Knowledge Management." Issues in Informing Science and Information Technology 5, (2008): 571-590.

18. Gratton, S. J., BI 3.0, What Does it Mean? The Journey to Business Intelligence. http://www.capgemini.com.technology, 2012.

19. Heisig, P., "Il Knowledge Management Sincronizzazione tra Persone, Processi eTecnologie Dell'informazione.” In: Bartezzaghi, Raffa, Romano (Eds.): Knowledge Management e-Competitività (Napoli: Edizioni Scientifiche Italiane, 2003), pp. 19-38.

20. Inmon, W. H., Building the Operational Data Store (2 ${ }^{\text {nd }}$ Ed.) (Wiley Publishers: New York, 1999).

21. Kebede, G., "Knowledge Management: An Information Science Perspective." International Journal of Information Management 30, (2010): 416-424.

22. Khan, R., "Dovetailing of Business Intelligence and Knowledge Management: An Integrative Framework." Information and Knowledge Management Journal 2(4), (2012): 16.

23. Klicon, The Role of Information Technology in Knowledge Management Within the Construction Industry. Project Report of Knowledge Learning in Construction Group at the Centre for Research in the Management of Projects. University of Manchester Institute of Science and Technology, 1999.

24. Kodama, M., "Customer Value Creation through Knowledge Creation with Customers: Case Studies of IT and Multimedia Businesses in Japan." International Journal of Innovation and Learning 2(4), (2005): 357-385.

25. Koenig, M. E. D., "The Third Stage of KM Emerges", KM World 11(3), (2002): 20-21.

26. Kothari, C. R., Research Methodology: Methods and Techniques (New Delhi: New Age International (P) Ltd, 2004). 
Issue $3 / 2017$

27. Madhoushi, M., Sadati, A., Delavari, H., Mehdivand, M. \& Hedayatifard, M., "Facilitating Knowledge Management Strategies through IT and HRM." Chinese Business Review 9(10), (2010): 57-66.

28. Mahmood, A., Qureshi, M. A. \& Shahbaz, Q., "An Examination of the Quality of Tacit Knowledge Sharing through the Theory of Reasoned Action." Journal of Quality and Technology Management VII(I), (2011): 39-55.

29. Metaxiotis, K., Ergazakis, K. \& Psarras, J., "Exploring the World of Knowledge Management: Agreements and Disagreements in the Academic/Practitioner Community." Journal of Knowledge Management 9(2), (2005): 6-18.

30. Muhammad, G. \& Ibrahim, J., "Business Intelligence as a Knowledge Management Tool in Providing Financial Consultancy Services." American Journal of Information Systems 2(2), (2014): 26-36.

31. Negash, S. \& Gray, P., "Business Intelligence." In F. Burstein \& C. W. Holsapple (Eds.), Decision Support Systems (Berlin: Springer, 2008), pp. 175-193.

32. Ngai, E. W. T. \& Wat, F. K. T., "A Literature Review and Classification of Electronic Commerce Research." Information \& Management 39(5), (2002): 415-429.

33. Nonaka, I., "The Knowledge-Creating Company." Harvard Business Review 69, (1991): 96-104.

34. Nonaka, I., "A Dynamic Theory of Organizational Knowledge Creation." Organization Science 5(1), (1994): 14-37.

35. Nonaka, I. \& Takeuchi, H., The Knowledge-Creating Company: How Japanese Companies Create the Dynamics of Innovation (Oxford University Press: New York, NY, 1995).

36. Olszak, C. M. \& Batko, K., "The Use of Business Intelligence Systems in Healthcare Organizations in Poland." Computer Science and Information Systems (FedCSIS), (2012): 969-976.

37. Olszak, C. M. \& Ziemba, E., "Business Intelligence Systems in the Holistic Infrastructure Development Supporting Decision-making in Organizations." Interdisciplinary Journal of Information, Knowledge and Management 1, (2006): 47-58.

38. Panian, Ž. \& Klepac, G., Poslovna Inteligencija (Masmedia, Zagreb, 2003).

39. Pateli, A. G. \& Giaglis, G. M., "A Framework of Understanding and Analyzing eBusiness Models." In Proceedings of the $16^{\text {th }}$ Bled Electronic Commerce Conference-e Transformation, June 9-11, Bled, Slovenia, (2003): 1-22.

40. Polanyi, M., Personal Knowledge (London, UK: Routledge \& Kegan Paul, 1973).

41. Power, D. J., A Brief History of Decision Support Systems. http://DSSResources.COM/ history/dsshistory.html,version4.0, 2007.

42. Radonic, G., "A Review of Business Intelligence Approaches to Key Business Factors in Banking." Journal of Knowledge Management Practice 8(1), (2007): 66-71.

43. Ranjan, J., "Business Intelligence: Concepts, Components, Techniques and Benefits." Journal of Theoretical and Applied Information Technology 9(1), (2009): 60-70. 


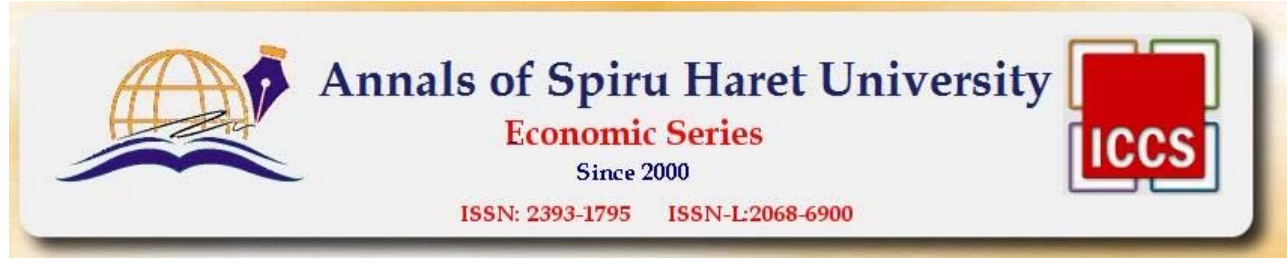

Issue $3 / 2017$

44. Rao, K. \& Kumar, R., "Framework to Integrate Business Intelligence and Knowledge Management in Banking Industry." Review of Business and Technology Research 4(1), Online Journal, July 2011.

45. Rašula, J., Vukšić, V. B. \& Štemberger, M. I., “The Impact of Knowledge Management on Organizational Performance.” Economic and Business Review 14(2), (2012): 147-168.

46. Sabherwal, R. \& Fernandez, I. B., Business Intelligence Practices, Technologies, and Management (John Wiley \& Sons, Inc. USA, 2011).

47. Scharmer, C. O., "Self-Transcending Knowledge: Sensing and Organizing Around Emerging Opportunities.” Journal of Knowledge Management 5(2), (2001): 137-151.

48. Schick, A., Frolick, M. \& Ariyachandra, T., "Competing With BI and Analytics at Monster Worldwide." Proceedings of the $44^{\text {th }}$ Hawaii International Conference on System Sciences, 2011.

49. Schultze, U. \& Leidner, D. E., "Studying Knowledge Management in Information Systems Research: Discourses and Theoretical Assumption.” MIS Quarterly 26(3), (2002): 213242.

50. Scott, N. (n. d.). The 3 Ages of Business Intelligence: Gathering, Analyzing and Putting it to Work, http://www.excapite.blogspot-ages-of-business-ontelligence.html

51. Senge, P., The Fifth Discipline: The Art and Practice of the Learning Organization (Currency/Doubleday: New York, NY, 1990).

52. Servin, G. \& de Brun, C., ABC of Knowledge Management (NHS National Library for Health: Knowledge Management Specialist Library, 2005).

53. Shehzad, R. \& Khan, M., "Integrating Knowledge Management with Business Intelligence Processes for Enhanced Organizational Learning." International Journal of Software Engineering and Its Applications 7(2), (2013): 83-91.

54. Sheung, C. T., "E-Business: The New Strategies Ande-Business Ethics, that Leads Organizations to Success." Global Journal of Management and Business Research XIV(VIII), (2014): 9-14.

55. Stackowiak, R., Rayman, J. \& Greenwald, R., Oracle Data Warehousing and Business Intelligence Solutions (Wiley Publishing, Inc., Indianapolis, 2007).

56. Strauss, J., El-Ansary, A. \& Frost, R., E-Marketing ( $3^{\text {rd }}$ Ed.) (New York: Prentice Hall, 2003).

57. Swan, J., Newell, S., Scarbrough, H. \& Hislop, D., "Knowledge Management and Innovation: Networks and Networking." Journal of Knowledge Management 3(4), (1999): 262-275.

58. Valacich, J. \& Schneider, C. (Eds.), Information Systems Today: Managing in the Digital World (4 ${ }^{\text {th }}$ Ed.) (New York: Prentice Hall, 2010).

59. Vorakulpipat, C. \& Rezgui, Y., "From Knowledge Sharing to Value Creation: Three Generations of Knowledge Management." Paper Presented at the IEEE International Engineering Management Conference, Salvador, Bahia, Brazil, 2006. 

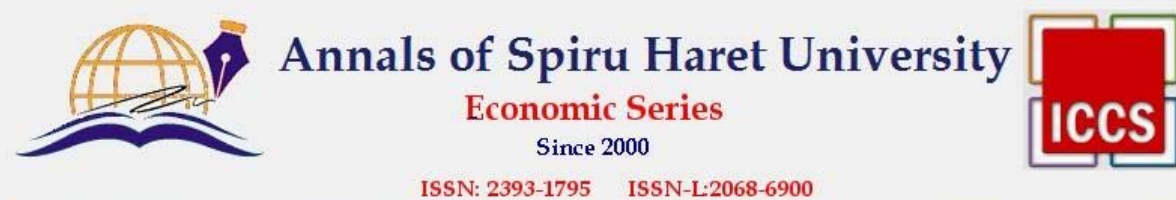

Issue $3 / 2017$

60. Wang, H. \& Ji, L., "An Effective Knowledge Management Environment Based on Knowledge Grid in Business Organizations." Communications of the IIMA 5(4), (2005): 91100.

61. Wang, H. \& Wang, S., "A Knowledge Management Approach to Data Mining Process for Business Intelligence." Industrial Management \& Data Systems 108(5), (2008): 622-634.

62. Wiig, K. M., "Knowledge Management: An Introduction and Perspective." The Journal of Knowledge Management 1(1), (1997): 6-14.

63. Wixom, B. H. \& Watson, H. J., "The BI-based Organization." International Journal of Business Intelligence Research 1(1), (2010): 13-28.

64.Zekić-Sušac, M., Sustavi Poslovne Inteligencije. Ekonomski Fakultet u Osijeku, http://oliver.efos.hr/nastavnici/mzekic/nast_materijali/poslovna_inteligencija.pdf, 2008. 